\title{
OPTIMALISASI PEMBELAJARAN IPS MELALUI PEMANFAATAN PETA PIKIRAN UNTUK MENINGKATKAN HASIL BELAJAR DAN KREATIVITAS SISWA KELAS IX
}

\author{
ENDAH SUTJIATI \\ SMPN 1 Pogalan \\ e-mail: endahsutji@gmail.com
}

\begin{abstract}
ABSTRAK
Dalam pembelajaran di kelas hendaknya memperhatikan beberapa aspek tidak hanya aspek kognitif dan afektif saja tetapi aspek psikomotorik juga perlu diperhatikan contohnya kreativitas siswa juga perlu diperhatikan. Apabila kreatifitas peserta didik dikembangkan sejak awal akan mampu membentuk kebiasaan cara berfikirnya yang sangat bermanfaat bagi peserta didik itu sendiri di kemudian hari.Dalam proses pembelajaran di kelas IX C SMP Negeri 1 Pogalan Kabupaten trenggalek belum semua siswa berperan aktif dalam proses pembelajaran di kelas. Permasalahan ini dapat terlihat pada saat guru menyampaikan pelajaran siswa cenderung pasif, diam dan kurang inisiatif. Hal ini disebabkan oleh rendahnya kreativitas siswa. karena pembelajaran masih dominan menggunakan metode ceramah sehingga sebagian besar siswa masih pasif dan pembelajaran berpusat pada guru(guru centris). Upaya yang diharapkan dapat membangkitkan kreatifitas siswa dalam pembelajaran IPS adalah menerapkan metode Peta Pikiran, yaitu dengan membelajarkan siswa cara mencatat yang baik yaitu melalui model pembelajaran Mind Mapping. Penerapan pembelajaran ini menekankan keaktifan dan kemandirian siswa, baik secara fisik amupun mental, siswa diberi kesempatan untuk belajar berfikir, menghafal, menghayati, bekerjasama, berinteraksi, kreatif, dan terampil.Penelitian ini bertujuan untuk mengetahui hasil belajar dan kreativitas siswa pada mata pelajaran IPS kelas IX SMP Negeri 1 Pogalan,. Penelitian ini menggunakan pendekatan kualitatif dengan jenis Penelitian Tindakan Kelas (PTK), yang dilaksanakan dalam 2 siklus. Dalam setiap siklus terdiri dari 2 pertemuan dan melalui 4 tahapan yaitu tahap perencanaan tindakan, tahap pelaksanan tindakan, tahap pengamatan, dan tahap refleksi. Adapun subjek penelitian adalah siswa kelas IX berjumlah 32 siswa. Penelitian ini dilakukan pada bulan Juli dan September 2018. Hasil penelitian mampu meningkatkan kreativitas dan aktivitas siswa dalam pemelajaran. Hal ini tampak dari rata-rata hasil penilaian kreativitas siswa dengan kategori kreatif dan sangat kreatif mengalami peningkatan dari $57 \%$ pada siklus 1 menjadi $67 \%$ pada siklus 2 , berarti terjadi peningkatan sebesar $10 \%$. Berdasarkan indikator keberhasilan, penelitian kreativitas siswa telah berhasil karena mencapai $67 \%$. Sedangkan untuk aktivitas siswa dalm kegiatan diskusi terlihat dari rata-rata hasil penilaian aktivitas siswa siklus 2 meningkat dibanding siklus 1 yaitu $25 \%$ aktif dan $75 \%$ kurang aktif mejadi $46 \%$ untuk siswa yang aktif dan 54\% kurang aktif. Sedangkan pendapat siswa tentang pembelajaran ini $82,87 \%$ setuju apabila dalam pembelajarn geografi menggunakan peta pikiran.
\end{abstract}

Kata kunci: Peta Pikiran, Hasil belajar, Kreativitas Siswa

\section{PENDAHULUAN}

Dalam pembelajaran di kelas hendaknya memperhatikan beberapa aspek tidak hanya aspek kognitif dan afektif saja tetapi aspek psikomotorik juga perlu diperhatikan contoh nya kreatifitas siswa juga perlu diperhatikan. Apabila kreatifitas peserta didik dikembangkan sejak awal akan mampu membentuk kebiasaan cara berfikirnya yang sangat bermanfaat bagi peserta didik itu sendiri di kemudian hari. Menurut Suyanto (2000) proses pendidikan yang ideal adalah proses pendidikan yang dikemas dengan memperhatikan adanya berbagai aspek baik kognitif, afektif, maupun psikomotor. Apabila proses pendidikan dapat dilakukan dengan memperhatikan adanya keseimbangan ketiga aspek tersebut maka out put pendidikan akan mampu mengantisipasi kemajuan dan perkembangan di masyarakat. 
Dalam proses pembelajaran di kelas IX C SMP Negeri 1 Pogalan Kabupaten trenggalek belum semua siswa berperan aktif dalam proses pembelajaran di kelas. Permasalahan ini dapat terlihat pada saat guru menyampaikan pelajaran siswa cenderung pasif, diam dan kurang inisiatif. Berdasarkan pengalaman mengajar selama ini terdapat kurang dari $10 \%$ siswa berani mengajukan diri untuk menjawab pertanyaan guru dan kurang dari $7 \%$ siswa berani mengemukakan pendapat atau mengajukan pertanyaan kepada guru. Hal ini berpengaruh pada rendahnya prestasi belajar siswa, yang terlihat dari hasil analisis pada setiap ulangan harian daya serap siswa di bawah $65 \%$ berarti secara klasikal kelas IX C belum tuntas belajarnya. Disamping itu pembelajaran masih dominan menggunakan metode ceramah sehingga sebagian besar siswa masih pasif dan pembelajaran berpusat pada guru(guru centris). Hal itu menunjukkan kualitas pembelajaran masih rendah.

Upaya yang dharapkan dapat memperbaiki kualitas pembelajaran IPS Geografi di kelas IX C SMP Negeri 1 Pogalan Trenggalek perlunya diterapkan metode pembelajaran yang inovatif yang memberi peluang kepada siswa untuk mengaktualisaikan diri. Berdasarkan pengamatan perlu dilakukan optimalisasi pembelajaran yang mengacu pada peningkatan kreatifitas siswa di SMP. Salah satu metode pembelajaran yang sesuai adalah pemanfaatan "Peta Pikiran". Metode pembelajaran pemanfaatan peta pikiran perlu dioptimalkan agar terjadi pembelajaran yang bermakna. Konsep pembelajaran dengan pemanfaatan peta pikiran adalah pembelajaran yang megaktifkan siswa dengan cara mengubah topik-topik dalam wacana menjadi bentuk gambar(menggambarkan) topik utama ditengah-tengah sedangkan sub topik dan perinciannya merupakan cabang-cabangnya. Peta pikiran yang baik yang menggunakan banyak gambar dan simbul serta warna-warni sehingga terlihat seperti karya seni. Dengan pemanfaatan peta pikiran dalam pembelajaran IPS Geografi seperti diuraikan di atas, siswa diharapkan dapat berperan aktif serta dapat menggali kreatifitasnya sehingga bias meningkatkan imajinasi dan kemampuannya dalam memahami materi pelajaran IPS Geografi

Menurut Porter dalam Sunarti (2003) Peta pikiran merupakan pendekatan keseluruhan otak yang mampu membuat catatan yang menyeluruh dalam satu halaman dengan menggunakan citra visual dan perangkat grafis lainnya, sehingga peta pikiran akan memberi kesan yang mendalam. Lebih lanjut menurut Mar'atus Solikah(2015) terjadi peningkatan kreativitas dan hasil belajar siswa dalam penerapan model pembelajaran mind mapping pada mata pelajaran ekonomi di SMA 8 Malang. Dewa Ayu Made Manu Okta Priantini (2016) juga berpendapat bahwa Metode Mind Mapping berpengaruh terhadap keterampilan berpikir kreatif dan prestasi belajar IPS. Pemanfaatan peta pikiran dalam pembelajaran IPS Geografi di kelas IX C diharapkan memberikan kontribusi yang positif dalam rangka optimalisasi pembelajaran IPS Geografi dalam upaya meningkatkan hasil belajar dan kreativitas siswa. Berdasarkan permasalahan di atas masalah yang akan dicari penyelesaiannya pada penelitian ini adalah: meningkatkan hasil belajar. Meningkatkan kreativitas melalui pemanfaatan peta pikiran. Secara umum penelitian ini bertujuan untuk meningkatkan hasil belajar dan kreativitas siswa kelas IX C di SMP Negeri 1 Pogalan Trenggalek melalui pemanfaatan peta pikiran.

Hasil penelitian ini diharapkan dapat memberikan kontribusi: (1) Bagi siswa : Dapat meningkatkan hasil belajar dan kreativitasnya sehingga diharapkan dapat selalu mengatisipasi perkembangan jaman. (2). Bagi guru : Memotivasi guru untuk selalu berusaha menemukan model pembelajaran yang lebih efektif dan merubah paradigma pembelajaran dari teacher centered (behaviorisme) ke students centered (kontruktivisme) di SMP, serta mengoptimalkan pembelajaran IPS. (3) Bagi lembaga sekolah: Sebagai bahan informasi, acuan dan masukan dalam menyelenggarakan program pendidikan. Untuk mengetahui hasil prestasi belajar siswa, penulis memberikan pengertian tentang belajar. Dalam kamus umum Bahasa Indonesia disebut bahwa :"Prestasi adalah kemampuan siswa yang semaksimal mungkin dari hasil yang dicapai"(W.J.S Poewodarminto, 1982:108) Menurut Suhartono, "Belajar adalah suatu nilai yang menunjukan hasil yang tinggi dalam belajar, yang dicapai melalui kemampuan dalam mengerjakan sesuatu pada saat tertentu pula." 
Dari sini dapat ditarik kesimpulan bahwa pretasi belajar siswa adalah nilai yang mewujudkan hasil belajar yang menunjukkan kemampuan dalam mengerjakan pada saat tertentu dalam suatu lembaga pendidikan. Jadi dari pengertian prestasi belajar tersebut di atas dan peristiwa mengajar yang mengarah pada tujuan, maka untuk mengetahui apakah kegiatan belajar mengajar akan berhasil atau sudah mencapai tujuan, yang diperlukan adalah nilai. Penilaian itu diperlukan untuk mengetahui hasil usaha pendidikan kita terhadap siswa, hasil inilah yang kita sebut prestasi belajar siswa. Kreativitas adalah kemampuan untuk menciptakan atau mengandung daya cipta (Adidarmojo : 2003) Sedangkan Porwadarminta (1976) menyakatan bahwa kreatifitas yaitu bersifat mencipta, misalnya pekerjaan yang kreatif menghendaki selain kecerdasan juga imajinasi. Menurut para ahli psikologi pada dasarnya bakat kreatif ada pada setiap orang. Bakat didorong oleh keinginan seseorang untuk menunjukkan jati diri kepada lingkungannya, yang akan membuat dia berusaha mengekspresikan diri sesuai dengan kapasitas dan kemampuannya. Kreativitas dapat dibentuk, diciptakan dan dikombinasikan kehadirannya dengan menciptakan suasana yang kondusif bagi tumbuh kembangnya kreativitas tersebut. Jadi kesimpulan dari berbagai pendapat tersebut adalah kreativitas merupakan kemampuan mencipta yang dimiliki oleh siswa didukung oleh kecerdasan dan imajinasi untuk menemukan bentuk-bentuk dan caracara baru.

Menurut Porter (1999) adalah metode mencatat kreatif yang memanfaatkan keseluruhan otak dengan menggunakan citra visual dan prasarana grafis lainnya untuk membentuk kesan. Metode ini berupa pola gagasan yang saling berkaitan dengan topik utama berada di tengah-tengah sedangkan sub topik dan perincian menjadi cabang-cabangnya. Peta pikiran yang baik yang menggunakan banyak gambar dan simbul serta warna-warni sehingga terlihat seperti karya seni. Peta pikiran ini merupakan komponen quantum learning yaitu bagaimana menciptakan dan membiasakan belajar yang nyaman dan menyenangkan. Adapun cara membuat peta pikiran adalah sebagai berikut: buatlah lingkaran di tengah-tengah kertas sebagai gagasan utamanya, buatlah cabang-cabang dari pusatnya untuk tiap-tiap poin kunci dengan pensil warna. Tuliskan kata kunci atau frase pada tiap cabang dan kembangkan untuk memberi keterangan, tambahkan simbul dan ilustrasi agar lebih menarik.

\section{METODE PENELITIAN}

Penelitian ini dilaksanakan dengan menggunakan pendekatan penelitian tindakan kelas yang setiap siklusnya dilaksanakan dua kali pertemuan. Prosedur yang digunakan dalam penelitian ini mengacu pada model Kemmis dan Taggart. Model ini merupakan model spiral karena tahap-tahap yang dilakukan dalam setiap siklus dari penelitian saling terkait satu dengan lainnya. Setiap siklus terdiri dari empat tahap, yaitu perencanaan, tindakan, pengamatan (observasi) dan refleksi. Siklus berikutnya dilakukan apabila siklus yang baru dilaksanakan belum mencapai indikator keberhasilan yang ditetapkan.

Penelitian tindakan kelas ini dilaksanakan di SMP Negeri I Pogalan di Kabupaten Trenggalek, JL Trenggalek-Tulungagung. Pembuatan rencana tindakan berdasarka refleksi yang ditulis pada proposal dilaksanakan pada bulan Juli sampai September 2018. Jam pelajaran 2 pertemuan setiap minggu masing-masing pertemuan 2 X 40 menit. Sebagai sasarannya adalah siswa kelas IX C SMP Negeri I Pogalan dengan jumlah siswa 32 orang. Nama-nama siswa yang terlibat disajikan pada lampiran 1. Guru IPS yang terlibat dalam penelitian ini adalah Endah Sutjiati, S.Pd sebagai peneliti dan anggota team guru sebagai kolaborator.

\section{HASIL DAN PEMBAHASAN}

\section{Hasil Penelitian}

\section{A. SIKLUS I}

Penelitian tindakan siklus 1 dilaksanakan mulai minggu ke 3 bulan Januari tahun 2018.

Bahan kajian siklus 1 adalah Negara Brunai Darusalam.

Kegiatan dalam penelitia siklus 1 antara lain: 


\section{Perencanaan}

Dalam tahap perencanaan kegiatan yang dilakukan oleh peneliti yaitu membuat contoh peta pikiran yang akan digunakan segagai bahan informasi pada siswa, menyiapkan wacana tentang Brunai Darusalam yang akan digunakan segagai bahan pemuatan peta pikiran, Menyiapkan instrument yang akan digunakan untuk pengamatan dan penilaian

\section{Pelaksanaan Tindakan}

Kegiatan pelaksanaan tindakan kelas pada siklus 1 terlihat seperti

Table 1 Kegiatan pelaksanaan tindakan kelas

\begin{tabular}{|c|c|c|c|}
\hline No & Kegiatan guru & No & Kegiatan siswa \\
\hline 1. & Membagikan soal pre tes & 1. & Mengerjakan soal pre tes \\
\hline 2. & $\begin{array}{l}\text { Memberikan informasi singkat } \\
\text { tentang materi pelajaran }\end{array}$ & 2. & $\begin{array}{l}\text { Mendengarkan/memperhatikan } \\
\text { informasi guru }\end{array}$ \\
\hline 3. & Membagi kelompok & 3. & $\begin{array}{l}\text { Siswamenuju kelompoknya masing- } \\
\text { masing }\end{array}$ \\
\hline 4. & $\begin{array}{l}\text { Membagikan wacana kepada } \\
\text { masing-masing kelompok }\end{array}$ & 4. & $\begin{array}{l}\text { Menerima wacana yang dibagikan } \\
\text { guru }\end{array}$ \\
\hline 5. & $\begin{array}{l}\text { Memantau pembuatan peta } \\
\text { pikiran dengan berkeliling }\end{array}$ & 5. & $\begin{array}{l}\text { Membuat peta pikiran secara } \\
\text { kelompok }\end{array}$ \\
\hline 6. & $\begin{array}{l}\text { Guru berperan sebagai fasilitator } \\
\text { dan motivator }\end{array}$ & 6. & $\begin{array}{l}\text { Presentasi hasil diskusi kelompok } \\
\text { dalam forum diskusi kelas }\end{array}$ \\
\hline 7. & $\begin{array}{l}\text { Bersama-sama siswa } \\
\text { menyimpulkan hasil diskusi }\end{array}$ & 7. & $\begin{array}{l}\text { Bersama-sama guru menyimpulkan } \\
\text { hasil diskusi kelas }\end{array}$ \\
\hline 8. & Membagikan soal post tes & 8. & Mengerjakan soal post tes \\
\hline 9. & Memberi tugas & 9. & Mencatat tugas \\
\hline
\end{tabular}

\section{Observasi dan Evaluasi Hasil Pantauan}

Hasil oservasi dapat dilihat dari hasil analisis data, tes dan lembar observasi. Adapun data hasil penelitian antara lain:

Tabel 2. Keaktifan siswa dalam diskusi

\begin{tabular}{|c|c|c|c|}
\hline \multirow[b]{2}{*}{ NO. } & \multirow{2}{*}{ Kelompok/siswa } & \multirow{2}{*}{ Nilai /Kategori } & Siklus 1 \\
\hline & & & Prosentase $(\%)$ \\
\hline 1 & - & A (Sangat aktif) & 10 \\
\hline 2 & - & B (Aktif) & 16 \\
\hline 3 & - & $\mathrm{C}$ (cukup aktif) & 19 \\
\hline \multirow[t]{2}{*}{4} & - & D (kurang aktif) & 55 \\
\hline & \multicolumn{2}{|c|}{ Jumlah } & 100 \\
\hline
\end{tabular}


Hasil rata-rata keaktifan siswa dalam kegiatan diskusi terlihat dalam histogram

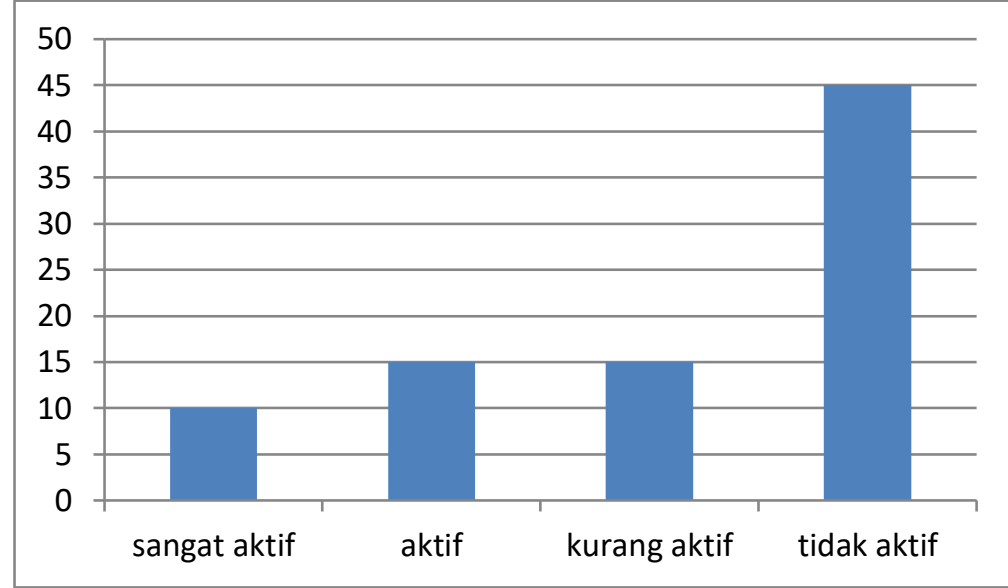

\section{Gambar 1. Grafik Hasil Rata-rata Keaktifan Siswa Dalam Diskusi}

Berdasarkan histogram 1 di atas dapat diketahui bahwa aktivitas siswa dalam kegiatan diskusi adalah sebesar $10 \%$ mempunyai aktivitas sangat aktif, $16 \%$ tergolong kategori aktif $19 \%$ tergolong kategori kurang aktif dan sebesar $15 \%$ tergolong tidak aktif 55\%. Ini berarti keaktifan siswa dalam kegiatan diskusi baik keterlibatan dalam kelompok maupun saat presentasi hasi diskusi, seperti siswa yang mau bertanya dan menanggapi jawaban teman sangat masih kurang.

Tabel 3. Kreativitas siswa

\begin{tabular}{|c|c|l|c|}
\hline \multirow{2}{*}{ NO. } & Kelompok/siswa & \multicolumn{1}{|c|}{ Nilai /Kategori } & Siklus 1 \\
\cline { 4 - 4 } & & - & $\begin{array}{c}\text { Prosen } \\
\text { tase(\%) }\end{array}$ \\
\hline 2 & - & A (Sangat kreatif) & 0 \\
\hline 3 & - & C (cukup kreatif) & 17 \\
\hline 4 & - & D (kurang kreatif) & 40 \\
\hline & \multicolumn{2}{|c|}{ Jumlah } & 43 \\
\hline
\end{tabular}

Hasil penilaian hasil kreativitas siswa tampak pada histogram di bawah ini!

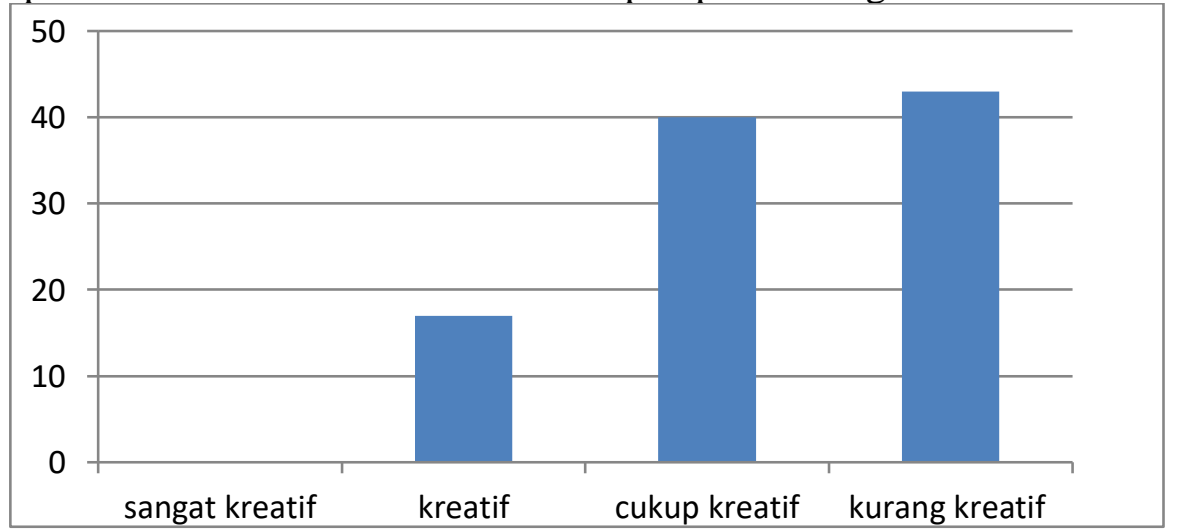

Gambar 2. Hasil penilaian hasil kreativitas siswa 
Berdasarkan histogram 2 nilai rata-rata kreativitas siswa pada siklus 1 menunjukkan bahwa 43\% siswa tergolong kategori kurang kreatif , 40\% tergolong kategori cukup kreatif, dan $17 \%$ tergolong kreatif, sedangkan yang tergolong sangat kreatif belum ada.

Tabel 4. Hasil Pre Tes Dan Post Tes

\begin{tabular}{|l|l|c|c|}
\hline No. & \multicolumn{1}{|c|}{ Kategori } & $\begin{array}{c}\text { Hasil Pre } \\
\text { Tes }\end{array}$ & $\begin{array}{c}\text { Hasil Post } \\
\text { Tes }\end{array}$ \\
\hline 1 & Sangat baik & $2,0 \%$ & $5,5 \%$ \\
\hline 2 & Baik & $20 \%$ & 28,5 \\
\hline 3 & Cukup & $37,5 \%$ & $36 \%$ \\
\hline 4 & Kurang baik & 40,5 & $30 \%$ \\
\hline & Jumlah & $\mathbf{1 0 0 \%}$ & $\mathbf{1 0 0 \%}$ \\
\hline
\end{tabular}

Rata-rata hasil belajar siswa seperti pada histogram berikut ini :

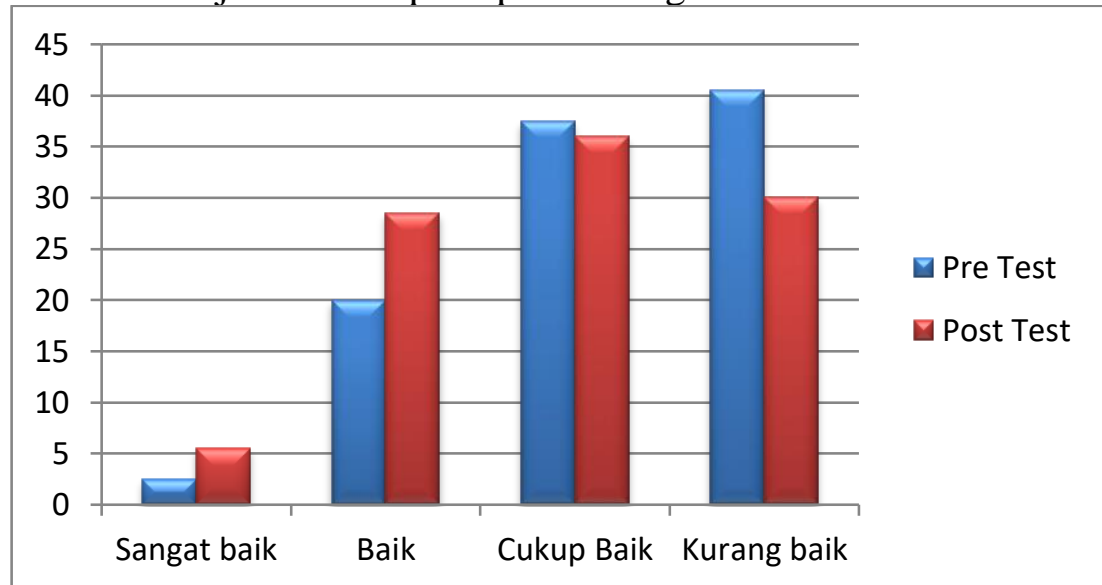

Gambar 3. Rata-rata hasil belajar siswa

Berdasarkan histogram 3 di atas dapat diketahui bahwa prestasi belajar siswa sebelum diadakan tindakan adalah sebesar $2 \%$ mempunyai prestasi belajar sangat baik, $20 \%$ tergolong kategori baik. 37,5\% tergolong kategori cukup baik dan sebesar 40,4\% tergolong kurang baik. Setelah diadakan tindakan maka prestasi belajar siswa mengalami perubahan. Hal ini dapat dilihat dari histogram hasil post tes yang menunjukkan bahwa 5,5\% mempunyai prestasi belajar sangat baik berarti ada peningkatan sebesar $3 \%$ di banding pre tes, kategori baik sebesar. 28,5\% terjadi peningkatan sebesar 8,5\% di banding pre tes, kategori cukup baik sebesar $36 \%$ terjadi penurunan sebesar 1,5\% di banding pre tes dan kategori kurang baik juga terjadi penurunan sebesar $10,5 \%$ yaitu dari $40,5 \%$ pada saat pre tes menjadi $30 \%$ pada saat post tes, dengan ketuntasan belajar klasikal $70 \%$.

\section{Refleksi}

Dari hasil observasi ditemukan kelemahan-kelemahan sebagai berikut: (a.) Dalam membuat peta pikiran siswa masih banyak menggunalan tulisan, sehingga peta pikiran hanya berupa ringkasan tertulis dari materi pelajaran. Hal ini menunjukkan bahwa siswa kurang kreatif belum dapat menggunakan imajinasinya dalam menciptakan simbol-simbol maupun gambar yang sesuai dengan tulisan. (b) Peta pikiran yang dibuat oleh siswa masih banyak yang belum meggunakan unsure warna karena banyak siswa yang tidak membawa spidol maupun pensil warna. (c.) Keterbacaan pata pikiran yang dibuat oleh siswa masih kurang. Hal ini diketahui saat siswa mempresentasikan hasil kerja kelompoknya penyaji sering berhenti karena lupa pada simbul yang digunakan. (d.) Siswa yang memiliki prestasi belajar kategori kurang baik masih sebesar 30\% dari 36 orang siswa. (e) Ketuntasan belajar klasikal kelas IX C baru mencapai $67 \%$ sehingga belum sesuai indikator penelitian dan kriteria ketuntasan belajar, hal ini perlu di tindak 
lanjuti dengan memberikan perbaika pada siswa yang elum tuntas belajarnya dan memberikan pengayaan bagi siswa yang telah tuntas belajarnya.

\section{B. SIKLUS II}

Penelitian tindakan siklus 2 menggunakan bahan kajian Negara Timor Leste Kegiatan dalam penelitia siklus 2 antara lain:

\section{Perencanaan}

Berdasarkan refleksi, observasi dan penilaian siklus 1, maka siklus 2 merupakan perbaikan dari siklus1. Rencana kegiatan yang dilakukan oleh peneliti pada siklus 2 antara lain: Mnginformasikan kepada siswa agar membawa spidol dan pensil warna untuk digunakan dalam pembuatan peta pikiran, menyiapkan wacana tentang Timor Leste yang akan digunakan sebagai bahan pemuatan peta pikiran, menambah waktu untuk pembuatan peta pikiran.

\section{Pelaksanaan Tindakan}

Pelaksanaan tindakan siklus 2 pada dasarnya sama dengan siklus 1, hanya pada siklus 2 ini diadakan perubahan-perubahan sesuai kekurangan dari siklus 1 sehingga diharapkan pada siklus 2 ini terjadi peningkatan baik kreativitas maupun prestasi belajar siswa. Perubahan yang dilakukan pada siklus 2 ini antar alain dengan menambah waktu pembuatan peta pikiran, menundi setiap kelompok yang akan tampil sehingga waktu untuk diskusi dan pembahasan lebih lama.

\section{Observasi dan Evaluasi Hasil Pantauan}

Tabel 5.Keaktifan siswa dalam diskusi

\begin{tabular}{|c|c|c|c|}
\hline \multirow{2}{*}{ NO } & Kelompok/siswa & Nilai /Kategori & Siklus 2 \\
\cline { 4 - 4 } & & & Prosentase(\%) \\
\hline 1 & - & A (Sangat aktif) & 11 \\
\hline 2 & - & B (Aktif) & 36 \\
\hline 3 & - & C (cukup aktif) & 19 \\
\hline 4 & - & D (kurang aktif) & 55 \\
\hline & \multicolumn{2}{|c|}{ Jumlah } & 100 \\
\hline
\end{tabular}
bawah ini.

Hasil rata-rata keaktifan siswa dalam kegiatan diskusi terlihat dalam histogram di

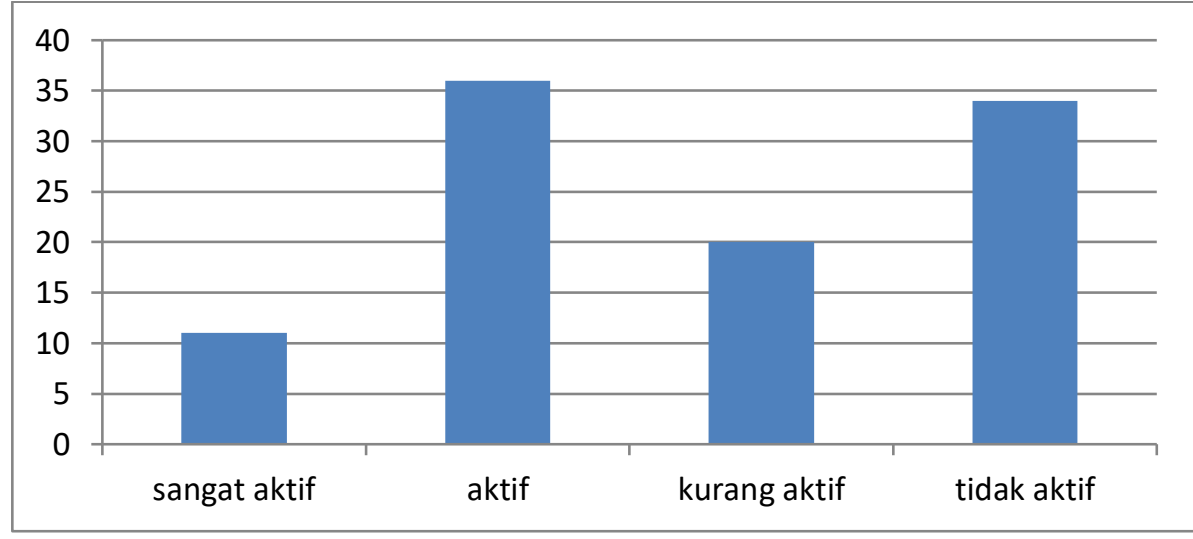

Gambar 4. Hasil rata-rata keaktifan siswa dalam kegiatan diskusi 
Berdasarkan histogram 4 di atas dapat diketahui bahwa aktivitas siswa dalam kegiatan diskusi pada siklus 1 sebesar 10\% mempunyai aktivitas sangat aktif menjadi sebesar $11 \%$ pada siklus 2, meningkat 1\%,16\% tergolong kategori aktif pada siklus 1 menjadi $36 \%$ terjadi peningkatan 20\%, 19\% tergolong kategori kurang aktif pada siklus 1 menjadi $20 \%$ pada siklus 2 terjadi kenaikan $1 \%$ dan yang tergolong tidak aktif terjadi penurunan sebesar $12 \%$ yaitu dari $55 \%$ menjadi $33 \%$. Secara keseluruhan pencapaian siklus 2 untuk aktivitas siswa dalam kegiatan diskusi $46 \%$ aktif dan 54\% kurang aktif hal ini berarti meningkat dibanding siklus1 yaitu $25 \%$ aktif dan $75 \%$ kurang aktif terjadi peningkatan $16 \%$ untuk siswa yang aktif dan penurunan untuk siswa yang kurang aktif. Ini berarti keaktifan siswa dalam kegiatan diskusi sudah mengalami peningkatan. Peningkatan keaktifan siswa tersebut meliputi jumlah siswa yang mau bertanya, mengemukakan pendapat dan menanggapi jawaban temannya baik pada waktu diskusi kelompok maupun saat presentasi dalam diskusi kelas.

Tabel 6. Hasil rata-rata kreativitas siswa siklus 2

\begin{tabular}{|c|c|l|c|}
\hline \multirow{2}{*}{ NO } & Kelompok/siswa & Nilai /Kategori & Siklus 2 \\
\cline { 4 - 4 } & - & A (Sangat kreatif) & $\begin{array}{c}\text { Prosen } \\
\text { tase }(\%)\end{array}$ \\
\hline 2 & - & B (kreatif) & 5 \\
\hline 3 & - & C (cukup kreatif) & 26 \\
\hline 4 & - & D (kurang kreatif) & 36 \\
\hline & \multicolumn{2}{|}{ Jumlah } \\
\hline
\end{tabular}

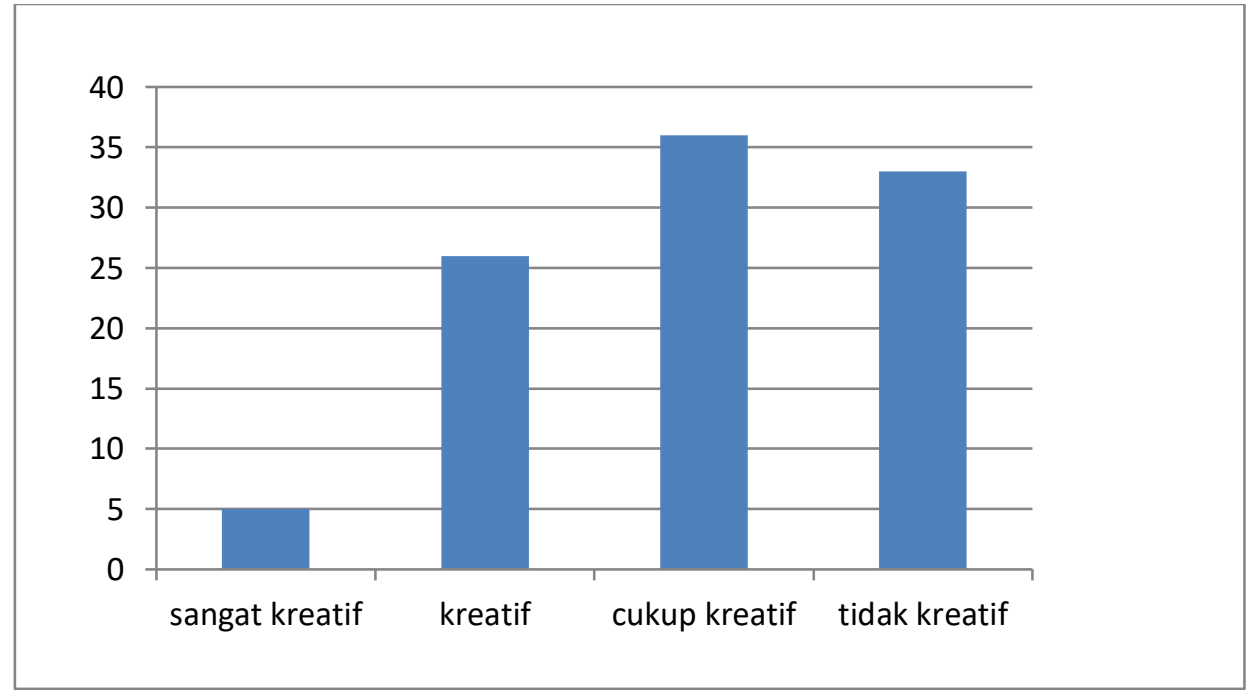

\section{Gambar 5. Nilai rata-rata kreativitas siswa}

Berdasarkan histogram 5 nilai rata-rata kreativitas siswa mengalami peningkatan dibanding siklus 1 . Pada siklus 1 siswa yang tergolong sangat kreatif belum ada, namun siklus 2 ini mencapai 5\%, siswa yang pada siklus 1 tergolong kreatif $17 \%$ menjadi $26 \%$ pada siklus 2 , terjadi peningkatan sebesar $9 \%$. Siswa yang tergolong kategori cukup kreatif pada siklus satu sebesar $40 \%$ turun menjadi $36 \%$ pada siklus 2. Disamping itu penurunan juga terjadi pada kategori kurang kreatif, dari $43 \%$ pada siklus 1 menjadi $33 \%$ pada siklus 2, terjadi penurunan sebesar $10 \%$. Secara keseluruhan pencapaian siklus 2 untuk kreativitas siswa $67 \%$ kreatif dan 
33\% kurang kreatif hal ini berarti meningkat dibanding siklus1 yaitu 57\% kreatif dan 43\% kurang kreatif terjadi peningkatan $10 \%$ untuk siswa yang kreatif dan penurunan untuk siswa yang kurang kreatif.

c. Rata-rata hasil belajar siswa seperti pada histogram berikut ini :

Tabel 7. Hasil Pre Tes Dan Post Tes

\begin{tabular}{|l|l|c|c|}
\hline No. & \multicolumn{1}{|c|}{ Kategori } & Hasil Pre Tes & Hasil Post Tes \\
\hline 1 & Sangat baik & $6 \%$ & $7 \%$ \\
\hline 2 & Baik & $29 \%$ & $35 \%$ \\
\hline 3 & Cukup & $34 \%$ & $36 \%$ \\
\hline 4 & Kurang baik & $31 \%$ & $22 \%$ \\
\hline & Jumlah & $\mathbf{1 0 0 \%}$ & $\mathbf{1 0 0 \%}$ \\
\hline & & & \\
\hline
\end{tabular}

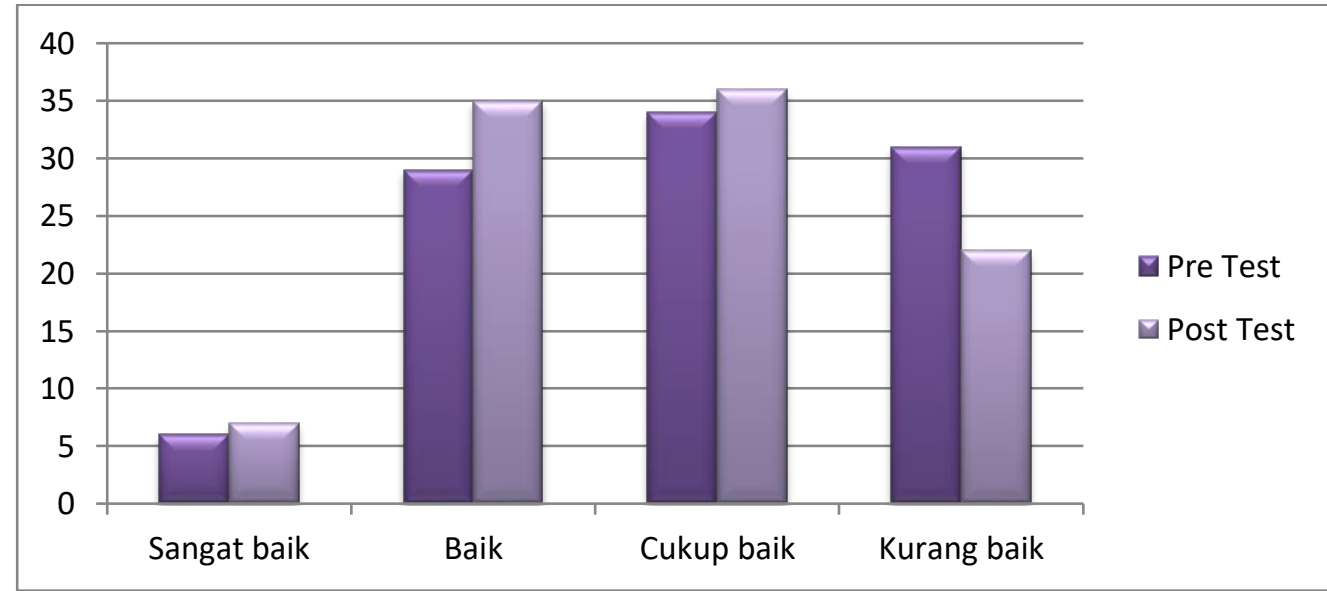

Gambar 6. Prestasi belajar siswa

Berdasarkan histogram di atas dapat diketahui bahwa prestasi belajar siswa sebelum diadakan tindakan adalah sebesar 6\% mempunyai prestasi belajar sangat baik, 29\% tergolong kategori baik. 34\% tergolong kategori cukup baik dan sebesar 31\% tergolong kurang baik. Setelah diadakan tindakan maka prestasi belajar siswa mengalami perubahan. Hal ini dapat dilihat dari histogram hasil post tes yang meujukkan bahwa $7 \%$ mempunyai prestasi belajar sangat baik berarti ada peningkatan sebesar $1 \%$ di banding pre tes, kategori baik sebesar. 35\% terjadi peningkatan sebesar $6 \%$ di banding pre tes, kategori cukup baik sebesar. $36 \%$ terjadi peningkatan sebesar $2 \%$ di banding pre tes dan kategori kurang baik terjadi penurunan sebesar $9 \%$ yaitu dai $31 \%$ pada saat pre tes menjadi $22 \%$ pada saat post tes, dengan ketuntasan belajar $88 \%$.

Apabila dibandingkan dengan siklus 1 maka ketuntasan belajar mengalami kenaikan dari $67 \%$ menjadi $88 \%$ pada siklus 2, berarti terjadi kenaikan sebesar $21 \%$. Berarti secara keseluruhan penelitian prestasi belajar siswa berhasil karena ketuntasan klasikal mencapai $88 \%$. Hasil wawancara dengan siswa

Tabel 8. Hasil wawancara dengan siswa

\begin{tabular}{|c|l|c|c|c|c|}
\hline No. & \multicolumn{1}{|c|}{ Pertanyaan } & SS & S & KS & TS \\
\hline 1 & $\begin{array}{l}\text { Pembelajaan dengan peta pikiran menurut saya } \\
\begin{array}{l}\text { Menimbulkan suasana pembelajaran tidak } \\
\text { membosankan }\end{array}\end{array}$ & 22,22 & 69,44 & 8,33 & - \\
\hline 2 & $\begin{array}{l}\text { Memudahkan dalam memahami materi } \\
\text { pelajaran }\end{array}$ & 22,22 & 61,11 & 16,66 & \\
\hline
\end{tabular}


Vol. 1 No. 2 September 2021, e-ISSN : 2797-8842 | p-ISSN : 2797-9431

\begin{tabular}{|c|l|c|c|c|c|}
\hline 3 & $\begin{array}{l}\text { Memudahkan dalam menghafal materi } \\
\text { pelajaran }\end{array}$ & 27,78 & 22,22 & 44,44 & 5,55 \\
\hline 4 & Menambah semangat belajar & 13,89 & 63,89 & 19,44 & 2,78 \\
\hline 5 & Meningkatkan imajinasi dan daya cipta & 58,33 & 41,67 & - & \\
\hline 6 & Memberi kesempatan siswa untuk berkreasi & 61,11 & 33,33 & 5,55 & \\
\hline & Jumlah & 205,55 & 291,75 & 94,42 & 8,33 \\
\hline & Rata-rata & 34,27 & 48,63 & 15,74 & 1,39 \\
\hline
\end{tabular}

\section{Pembahasan}

Berdasarkan hasil wawancara dengan siswa dapat disimpulkan bahwa 34,27\% siswa sangat setuju, 48,63\% menyatakan setuju apabila dalam pembelajaran geografi menggunakan media peta pikiran dengan alasan bahwa suasana pembelajaran tidak membosankan, lebih mudah memahami pelajaran, lebih mudah menghafalkan materi, lebih meningkatkan imajinasi dan kreatifitas serta dapat menambah semangat belajar. Sedangkan siswa yang kurang setuju $15,74 \%$ dan tidak setuju hanya $9 \%$ dengan alasan lebih senang mendengarkan informasi dari guru yaitu dengan metode ceramah. Hal ini merupakan bukti bahwa metode ceramah sudah terlanjur berakar dalam kegiatan pembelajaran sejak SD sampai SMP. Jadi secara keseluruhan kelas IX C menyatakan setuju apabila dalam pembelajarn geografi menggunakan peta pikiran. Dari hasil analisis data pada siklus 2 ditemukan beberapa kekurangan sebagai berikut: (a). Dalam membuat peta pikiran siswa masih banyak yang belum lengkap. Salah satu kendala dalam pembuatan peta pikiran di kelas adalah terbatasnya waktu sehingga siswa tidak bisa secara bebas menuangkan imajinasinya.(b). Masih banyak siswa yang belum bisa berkreasi karena tugas dilakukan secara kelompok, dan yang bisa meggambar dengan baik hanya beberapa orang saja. Hal ini berkaitan dengan bakat masing-masing siswa.

\section{KESIMPULAN}

Berdasarkan hasil penelitian tindakan yang telah dilaksanaka di kelas IX C maka dapat disimpulkan sebagai berikut: (1) Pemanfaatan peta pikiran mampu meningkatkan kreativitas dan aktivitas siswa dalam pemelajaran. Hal ini tampak dari rata-rata hasil penilaian kreativitas siswa dengan kategori kreatif dan sangat kreatif mengalami peningkatan dari $57 \%$ pada siklus 1 menjadi $67 \%$ pada siklus 2, berarti terjadi peningkatan sebesar $10 \%$. Berdasarkan indikator keberhasilan, penelitian kreativitas siswa telah berhasil karena mencapai 67\%. Sedangkan untuk aktivitas siswa dalm kegiatan diskusi terlihat dari rata-rata hasil penilaian aktivitas siswa siklus 2 meningkat dibanding siklus 1 yaitu $25 \%$ aktif dan $75 \%$ kurang aktif mejadi $46 \%$ untuk siswa yang aktif dan 54\% kurang aktif. Sedangkan pendapat siswa tentang pembelajaran ini $82,87 \%$ setuju apabila dalam pembelajarn geografi menggunakan peta pikiran. (2.) Pemanfaatan peta pikiran dapat meningkatkan hasil belajar siswa. Hal ini ditunjukkan dari peningkatan hasil belajar siswa yang tergolong baik dan sangat baik sebesar 67\% Pada siklus 1 menjadi $88 \%$ pada siklus 2, berarti terjadi peningkatan sebesar $21 \%$. Berdasarkan indikator keberhasilan, penelitian kreativitas siswa telah berhasil karena mencapai ketuntasan belajar $88 . \%$.

\section{DAFTAR PUSTAKA}

Adidarmojo, G.W. (2003). Peningkatan Kreatifitas Siswa dalam Pembelajaran Peribahasa. Gerbang : Majalah Pendidikan.40

Buzan, Tony. (2007). Mind Map untuk Meningkatkan Kreativitas. Jakarta: PT Gramedia Pustaka Utama.

De Porter, Boobi \& Hernacki,Mike. (1999). Quantum learning memiasakan belajar nyaman dan menyenangkan. Bandung : Kaifa

Dewa Ayu Made Manu Okta Priantini. (2016). Pengaruh Metode Mind Mapping Terhadap Keterampilan Berpikir Kreatif Dan Prestasi Belajar Ips Widya Accarya

Kamus Besar Bahasa Indonesia.1991 Depdikbud 
Mar'atus Sholihah. (2015). Penerapan model pembelajaran mind mapping untuk meningkatkan kreativitas dan hasil belajar siswa pada mata pelajaran ekonomi kelas $X$ IPS di SMA Negeri 8 Malang.Prosiding Seminar Pendidikan Ekonomi jurnal.fkip.uns.ac.id

R Rahayu, A Suyitno, E Sugiharti. (2012). Keefektifan Pembelajaran Kooperatif Model Mind Mapping Berbantuan Cd Pembelajaran terhadap Hasil Belajar. journal.unnes.ac.id

Sunarti, Titik. (2003). Pemanfaatan Peta Pikiran Sebagai Upaya Meningkatan Kreatifitas dan Prestasi Belajar Siswa Kelas III E Di SLTP Negeri Banguntapan. Makalah simposium guru 6 : Batu

Suyanto \& Jihad. (2000). Pendidikan di Indonesia memasuki Milenium III. Yogyakarta : Adi Cipta 